\title{
Evaluate the performance of certification competence vocational students through certification institute profesi-p1 program computer engineering expertise and tissues at south sumatra
}

\author{
Dian Nurdianto ${ }^{1}$, Syarwani Ahmad ${ }^{2}$, Mulyadi Mulyadi ${ }^{3}$ \\ ${ }^{1}$ Sekolah Menengah Kejuruan Negeri 1 Penukal, Indonesia \\ ${ }^{2}$ Universitas PGRI Palembang, Indonesia
}

\begin{tabular}{l} 
Article Info \\
\hline Article history: \\
Received Jul $17^{\text {th }}, 2021$ \\
Revised Aug $15^{\text {th }}, 2021$ \\
Accepted Aug $30^{\text {th }}, 2021$ \\
\hline
\end{tabular}

\section{Keyword:}

Serfitikasi evaluation

Competence

School.

\begin{abstract}
This study attempts to evaluate the performance of certification competence described vocational students through certification institute profesi-p1 program computer engineering expertise and tissues at south sumatra. This study in a qualitative descriptive with those cases .Data collection techniques used in this research was the questionnaire, interview, and use a method of triangulation dokumentasi.teknik data analysis and collect information or data from various sources to check the truth of the data.The results of the study conclude that so it can be seen that the purpose of the vocational school vocational certification in 1 penukal with objectives set the national profession certificates show category in accordance with the percentage of $75 \%$ Sedangkan to state 1 indralaya south objectives set the national profession certificatesshow category in accordance with the percentage of only $72 \%$.
\end{abstract}

(C) 2021 The Authors. Published by IICET.

This is an open access article under the CC BY-NC-SA license

(https://creativecommons.org/licenses/by-nc-sa/4.0

\section{Corresponding Author:}

Nurdianto, D.,

Sekolah Menengah Kejuruan Negeri 1 Penukal, Indonesia

Email: dhiyan_dra1@yahoo.com

\section{Introduction}

The implementation of the skills in one piece smk is important in the implementation of national examinations for student.In addition permendiknas number 28 year 2009 have explained that results from the implementation of the skills taken as an indicator of in standards of graduates, for stakeholders related information on competence would be used as owned and controlled the labor.Skills to the implementation of the meeting requirements and excellent standart appointed equipment and materials and equipment needed to support the implementation of competency test.One of essential competency test is in the verification of test site.

In practice a lot of competency test found that enforcement is not in accordance with the guidelines of. as expected. It can be seen with less facilities for the execution of the competency test and allocation of time used also. is still inadequate. Moreover in terms of the implementation of competency test had not reflected in accordance with standard capability owned required in the workplace because they have not been test-fired competence through professional certification institute, but that is so vital skills test and recognition of 
competencies owned, schools for graduate students so very necessary research on vocational competency test through professional certification institute.

Competency test in one success in implementation of schools accomplished when all competency test have aspects in the value of the quality of being high. Aspek in the covering the aspects of context, input, party, and prouduct.Context, covering the policy the purpose, demands capacity building and the graduates computer techniques and tissues at the business world progress / industry and science and technology.The input include support of human resources (assessors), infrastructure, device asesmen and a competency test.Party, the allocation of time, covering work procedures, the the observation skills. The product covering the documentation or value the competency and a certificate of competency.

Based on the object has done by researchers in state 1 South Indralaya Ogan Ilir, through interviews with of assessors technique of computers and tissue in 2020, june shows that in fact still a problem occurring in the implementation of the vocational certification of them 1) competition in labor market Indonesia with labor in foreign to Indonesia after the mea; 2) there are many graduates Jakarta / SMK students have a job in accordance with area of expertise in causeSMK graduates not of things in with competence required to the business / industry; 3) vocational there were still many schools that are not yet ready in implementing [1] about revitalization SMK; 4) vocational school graduates have not implement certification vocational school graduates of so limited vocational So that the limited vocational high school graduates certificates of competency of national board certification profession (BNSP ); 5 ) have had little vocational high school in partnership with the business world / industry in an effort to marketing 6 ) the certification test competence vocational school vocational students program computer engineering expertise and tissue by certification institute profesi- 1 in south sumatra province have never done Evaluation. The issue, suggests an indication that certification vocational competence there are many there is a shortage of.To improve certification vocational competence in smk located in the South Sumatra, badly needed evaluation of the implementation of these activities to understand the extent of the success and he knows deficient so that can be repaired certification vocational competence in the future. With safety evaluating the certification vocational competence is expected to be known how will the process of vocational certification done so that it can produce school graduates who is really ready to work and competitive in search of employment opportunities either by berwirausaha herself or ended up being in labor firms working with a standard competence The evaluation is done to know how the level of between the activities conducted by vocational school with the guidebook certification to student.Was a process systematic evaluation process of portraying, covering have, reported, and apply descriptive information and evaluate the information about the merits of some object, feasibility, honesty, safety, [2]. It with it so program evaluations from lack of to produce a solution so that when there are improvements in the will to come.Hence, then the researcher would will review more in the deferent of " certification evaluation vocational student through certification institution profesi-p1 skill computer program technique and tissues at selatan use cipp sumatra modelCIPP".

\section{Method}

This research use qualitative research was conducted as procedure research that yields data in the form of descriptive of words written or spoken of other people and behavior that observed. So, in the qualitative study although the data obtained can be counted and delivered in the form of the figures, but analyzing of qualitative. A subject in this research is a head of school, head of part the field of certification , assessors competence, and school tuition class xii skills computer technique and tissues .For the number of school tuition class xii technique computer and tissues were 106 people with details 25 school tuition from SMKN 1 Penukal,Penukal Abab Lematang Ilir and 81 school tuition from SMKN 1 Indralaya South Ogan Ilir.Technique data collection used in this research was the questionnaire, interview, and documentation..

\section{Results and Discussions}

Based on the research findings of known that certification activities handled by committee members and certification institution profesi.setiap committee members having the tasks and functions of each.The tasks and functions of the written in the basic vocational certification state Penukal and 1 state Indralaya 1 year South 2020 / 2021, a and certification institute profession also have in accordance with the national body sertificacy profession.

Obstacles or constraint in implementing certification were not there is a problem which means or the competency test, hinders a process competency test, wherein participants competency test matter, competency 
test of material, and competency test conditions have met the requirements set.Process giving the recommendation in state Penukal and 1 state 1 South Indralaya done by a profession certificates. The school only competency test results accepted are given sertfikasi profession institutions in the certification decision. And judgment has been in line based on standards used and processes pengukurannya, [3] Be grouped into (1), competency test that is a process of measuring and assessing their mastery of expertise someone based on against competencies, were required and apply in the company/a particular industry (enterprise standard) and or on the basis demands the needs of certain jobs; and (2) the profession, the process of skill and judgment mastery someone, penguasaannya against a standard based on ability competence they to manifest the professional and authorized a particular occupation, on the according to the standard of official raw which prevail at a kind of professional skill certain.

The evaluation process in vocational 1 Penukal and vocational 1 Indralaya South needed repairs especially the professional test. This is done so that vocational 1 Penukal and vocational 1 Indralaya South graduates have a guarantee that are relevant and competent. Evaluasi third evaluation process certification. vocational components. Components that are not yet available in truth is giving a certificate of competency.

Certificates that were issued after implementation sertifkais vocational in state vocational schools 1 penukal and state vocational schools 1 Indralaya South only consisted of 1 kind of the setifikat competence issued by the agency national setifikasi profession Dakam this is certification institution the profession melksanakan competency test. Result an assessment of steps certification vocational shows that $60 \%$ of the use of steps certification vocational in state vocational schools 1 Penukal and state vocational schools 1 Indralaya South a pretty reasonable by steps certification vocational set by the national profession certificates. Analysis the achievement of competence lessons in school needs to be done to know facilities that is not available in school but needed in an effort to meet competence school tuition in accordance with the curriculum set. With this move will be to know what facilities not available on schools but in fulfilling the needs of students in the curriculum

The matter certification activities necessary to certificate vocational event participants for certificate can implement directed and suitable for the need to certification sekolah.penyusunan matter vocational involving the principal, teachers, administrative staff, school dudi, and parents.For coordinating the programs established in the competence, : and certification.

The importance of the analysis of competence those lessons in schools and vocational preparation of material certification activities for the certification in vocational school vocational Penukal 1 and 1 south must state indralaya improved and the addition of , that the next. Gets better and on the results of the evaluation process , are needed to improve the evaluation process 1; certificate the process of giving 2 and 3 improvement in the vocational certification.

\section{Conclusions}

Based on the research, the have known that the purpose of the vocational state certification in 1 Penukal with the set of national agency profession certificates show category in accordance that $75 \%$ to the. State 1 South Indralaya objectives set of national agency profession certificates show in the category that only $72 \%$.

\section{References}

[1] Intruksi Presiden Nomor 9 Tahun 2016 tentang Revitalisasi SMK

[2] Stufflebeam \& Shinfield.(2007). Evaluation theory, models and aplications. San Fransisco: Jossey-Bass.

[3] Dikmenjur.(2008). Kurikulum SMK.Jakarta: Dikmenjur. 
